\title{
AN ATTEMPT AT MEASURING THE FISCAL INFLUENCE OVER ACCOUNTING OF ROMANIAN LISTED COMPANIES
}

\author{
Dan Dacian Cuzdriorean ${ }^{1}$ \\ Szilveszter Fekete ${ }^{2}$ \\ Lucia Sucală $\breve{3}^{3}$
}

\begin{abstract}
This paper we seek to measure the fiscal influence over accounting on a de facto level, empirical analysis is being performed on companies listed on the Bucharest Stock Exchange (BSE) and RASDAQ market, on a sample of 210 companies. Our observation was conducted in the year 2008, the variables taken in the analysis being sales as proxy for 'accounting' and income tax as measure for tax effects. The model we use is defined in a dynamic fashion (marginal values) since we believe these variables reflect the best the "true" variations of accounting and tax numbers.

The statistical results obtained show that there is a statistically significant influence of taxation over accounting of 4\%; we are not able, however, to say if this amount is "large" or "small", in since we have no benchmark value yet. This is also the first empirical tax research paper in accounting on Romanian data.
\end{abstract}

Key word: accounting, taxation, income tax, listed companies, Romania

JEL Codes: H2O; H25; M40; M41

\section{Introduction}

The subject of relationship between accounting and taxation is an evergreen and ever topical issue, especially in continental Europe, where the state has by tradition a strong implication in the economy (Walton et al., 2003). Due to this influence, accounting is not only the informational support of investors, as is considered by IASB (IASB, 2008, Framework), but also the most important informational source of the state (Berinde and Răchişan, 2005).

Many authors and practitioners affirm that accounting is influenced by taxation (as presented in the literature review section), but few of them focus on the level of this influence. How much is accounting information "altered" by fiscal considerations? To what extent are the accounting numbers influenced by tax considerations? In our study we try to find a de facto measure for this influence, testing the proposed model on Romanian data.

The importance of this study relates to the fact that, to our current knowledge, there is no such attempt in the literature to measure the fiscal influence over accounting in any of the east European countries. The model we propose not only captures the relationship between these two phenomena, but also provides a basis for statistical (significance) testing. On the other hand we believe that all parties participating in the financial reporting process, such as accountants, auditors, users of financial information, accounting and assurance standard setters and fiscal authorities must understand the implication of taxation in accounting. This is the case in continental Europe, and in

\footnotetext{
1 PhD Student, Babes-Bolyai University, Faculty of Economics and Business Administration, dan.cuzdriorean@econ.ubbcluj.ro

$\frac{1}{2}$ Lecture PhD, Babes-Bolyai University, Faculty of Economics and Business Administration, szilveszter.fekete@econ.ubbcluj.ro

Associate Professor PhD, Babes-Bolyai University, Faculty of Economics and Business Administration, Lucia.sucala@econ.ubbcluj.ro
} 
many non-Anglo Saxon countries where the state has strong implication in the economic and social life.

\section{Some theoretical considerations}

The accounting represents a privileged source of information for fiscal authorities. It is tried and is trying often to establish a relationship between tax policy and accounting, in order to indicate the direction of influences. Therefore, following scenarios can be identified (Istrate, 1999):

- accounting is influenced by taxation, with varying degrees of intervention;

- accounting is independent of tax (both are disconnected);

- tax is influenced by accounting.

In any of these cases one thing is certain: there is interdependence between accounting and taxation.

Lamb, Nobes and Roberts (1998) propose the following causality model for linkage between tax and financial reporting:

- Disconnection: The different tax and financial reporting rules (or different options) are followed for their different purposes.

- Identity: Identity between specific (or singular) tax and financial reporting rules.

- Accounting leads: A financial reporting rule or option is followed for financial reporting purposes, and also for tax purposes. This is possible because of the absence of a sufficiently specific (or singular) tax rule.

- Tax leads: A tax rule or option is followed for tax purposes, and also for financial reporting purposes. This is possible because of the absence of a sufficiently specific (or singular) financial reporting rule.

- Tax dominates: A tax rule or option is followed for tax and financial reporting purposes instead of a conflicting financial reporting rule.

When accounting is connected to taxation (Ristea, 1995) accounting objectives can be fulfilled only through the filter of tax, which may distort the meaning of accounting information (Istrate, 1999). Regarding the fundamental objective of accounting (Feleagă, 1999), this will depend on the relative importance of various legal forms of enterprise, the ways of financing preference and general attitude towards the concept of openness and confidence. Such an attempt to understand the concept of relationship between accounting and taxation requires complex theoretical and practical expertise in both taxation and accounting, and studying this interaction in the accounting practice is exciting (Sucală, 2002). Many specialists tried to disentangle this relationship through analytical and empirical analysis in different countries, which is discussed in the next section.

\section{Literature review}

There is a significant body of taxation research in accounting worldwide, many of them being published in local languages, since taxation is usually considered a local issue. Therefore, papers published in this field vary significantly by regions and languages (Anglo-Saxon countries, continental European countries for example) and also by the methods applied (descriptive/analytical and empirical).

In our attempt to understand several approaches used by researchers, we reviewed the international literature published in English language since 1990, as well as local literature published in Romanian, Hungarian and also Spanish language. The mainstream in this kind of research could be considered the analytical approach, since the large majority of the papers processed by us use analytical research tools. We focused here more on empirical papers in order to position our analysis among this research stream. Since in Romania there is no prior empirical paper on taxation-accounting relationship, we addressed descriptive studies to review the current state of knowledge in the literature. 


\section{Review of international literature}

Hoogendoorn (1996) realized an overview of the relationship between accounting and taxation those thirteen European countries. In the article is made the distinction between accounting and taxation dependence, and accounting and taxation independence. It is made a comparison of relationship for deferred tax between countries, the study including six countries where accounting and taxation are dependence, and seven countries where accounting and taxation are independence, the conclusion being that the relationship between countries is very different across the Europe.

Lamb, Nobes and Roberts (1998) assessing the degree of connection between tax rules and practices and financial reporting rules by studying the five types of connection and disconnection (see previous section), the method used was applied in four countries (UK, USA, France and Germany). The analysis was based on 15 items that can measure the influence of taxation over accounting. The results conclude that in UK and USA, the accounting are disconnected by taxation, unlike in France and Germany where is a binding link between accounting and taxation.

Nobes et al. (2004), based on study conducted by Lamb et al. (1998), measure the links between tax and financial reporting in Spain. The authors refute the proposition in the literature which says that link between tax/accounting has been reduced substantially from 1990.

Other studies analyzed the relationship between accounting and taxation in Spain: Chauveau (1995), Martinez and Labatut (1997), Gallego and Garcia (1999), Gallego (2004).

Chaveau (1995) conducted a descriptive analysis regarding tax dominance, the author concluded that implementation of the Directives was a good opportunity to move away from tax domination. Gallego and Garcia (1999) analyzed accounting and taxation aspects in joint ventures, the authors showing that there are many cases where firms apply special tax rules but do not disclose any information on the matter.

Martinez and Labatut (1997) conducted empirical analyses on application of the inter-period tax allocation - tax into account the differences that occurred in the 1992 accounting period, considering the accounting and taxation rules in force at the moment in Spain. The authors concluded that significant differences in their sample periods were those motivated by leasing transactions and deferred tax liabilities (negative temporary differences) have been increasing in number over time.

Gallego (2004) analyses the behavior of listed Spanish firms in this accounting-taxation relationship 1996-1998, the extent of introduction of the inter-period income tax allocation method, and the number and types of permanent and temporary differences reported. The findings are related to the fact that most firms adopt the income tax allocation method, and report the differences, although they do not always specify which transactions provoked them. Among the long list of operations that generate differences, the most frequent are income tax expense, welfare schemes, provision for pensions, monetary correction, accelerated depreciation, or exemption for reinvestment.

Blake et al. (1993) conducted an descriptive analyze of the relationship between accounting and taxation in Germany, Spain and UK, the authors related that between three countries are differences, as: (1) in Germany has a binding link between accounting and taxation; this is attributable to a broader set of user needs for which a conservative approach to accounting is appropriate: (2) in UK the relationship between accounting and taxation is strong both in principle and in practice, the accounting standards have been formulated in response with tax consideration, and tax authorities are adapting their approach in response to accounting standards; (3) in Spain the relationship between accounting and taxation is has been strong, but it is a major change in the relationship as a result of implementation of the EC Fourth Directive.

Blake et al. (1998) examine accounting regulations in Spain, Sweden and Austria, highlighting the key regulatory issues of the "true and fair" view requirement and the link between taxation and accounting, as an important step to harmonization of accounting practice. 
Blake et al. (1997) analyses the link between accounting and taxation for Swedish case which offers a formal legal accounting system based on a binding tax-accounting link and a privatesector, standard-setting body seeking to break this link. In this respect the authors analyzed the range of arguments put forward in the literature for and against the binding link, and identifying ways in which professional accountants have sought to circumvent the impact of the link and considering the effect of the link on the three bodies in Sweden involved in formulating accounting regulations and recommendations.

Aisbitt (2002) conducted an analysis regarding the relationship between rules for computing profits for tax and accounting purposes in Denmark, Norway, Sweden and Finland. The author mentioned that a possible alternative to breaking the tax link (related to accounting) is through promoting the harmonization of taxation as well as financial reporting.

Eberhartinger and Klostermann (2007) realized a simulation of differences in the discounted tax burden if IFRS were relevant for taxation, in various scenarios, on a sample comprising 61 Austrian companies. The empirical study is done from the Austrian balance sheet through its implementation of IFRS format, with an IFRS factor and tax factor. Analysis is done at the sector level and size, based on 3 scenarios (1) IFRS are fully and without any restriction relevant for taxation; (2) IFRS are relevant for taxation except for all cases where measurement above historical cost is involved; (3) IFRS are relevant for taxation under the assumption that the present mandatory tax rules are maintained. The overall result (for all scenarios, for all sectors included and for all sizes) is that the discounted tax dis-/advantage is very small.

Tzovas (2006) investigates the factors that influence the accounting policy decisions of firms operating in Greece. The study investigates whether non-tax considerations can influence firms' accounting-policy decisions and prompts them to deviate from a tax-reducing policy. The empirical analysis concluded that accounting figures influence firms' stakeholders' perceptions and decision-making, and firms pursue profit-related objectives that may not coincide with the objective of minimization of firms' tax liability.

Stoianoff and Kaidonis (2005) exploring both, accounting standards and the taxation provisions with respect to the treatment of rehabilitation costs of mining entities in Australia. The descriptive analysis show that the mining company, accounting standards and the taxation system act seemingly independently to privilege a particular class of citizen (providers of capital), while at the same time claim to be acting for the benefit of society as a whole. The independence of these institutions acts to obfuscate their role in perpetuating the privileges, powers and impact on the society in which they claim to serve.

In USA also was developed a lot of studies regarding the relationship between accounting and taxation, in USA accounting is disconnected by taxation. Guentther et al. (1997) analyzed the effects of taxation on the informativeness of accounting earnings in US companies, the authors concluded that when firms are required to switch for tax purposes from the cash method of accounting to the accrual method, firms deferred more income for financial reporting purposes because of the increased trade-off between financial accounting and tax. Manzon and Plesko (2002) and Scholes et al. (2005) analyzed the factors that influence the tax law. The empirical analysis showing that tax law is being influenced by political, social and economic objectives rather than the information needs of investors. Desai (2005) conducted a descriptive analysis regarding the effects of increasing conformity between accounting and taxation. The results concluded that the increasing conformity can improve the informativeness of financial accounting earnings by constraining earnings management. Hanlon et al. (2008) conducted an empirical study regarding the behavior which tax-induced changes in financial reporting. The results concluded that when the links between financial reporting and tax become stronger the informational role of accounting earnings is reduced.

As the CEE countries are concerned, there is already some empirical evidence from previous literature concerning fiscal influence over accounting in CEE. Pavlik (2001), for example, using 
value-relevance methodology found that deferred taxes are not significant for share prices in case of Hungarian listed companies.

Bosnyák (2003) studied in Hungary the accounting policy choices of both large corporations and SMEs. His findings confirm the de facto impact of taxation on accounting, since the strongest factor was the "taxation", explaining $26.17 \%$ of decisions made by accountants in their accounting policy choices. Based on his framework, Fekete et al. (2008) found also important influence of taxation on accounting (albeit the factor analysis applied contained high amount of noisy factors also).

Sucher and Jindrichovska (2004) analyzed the impact of implementing the IFRS in Czech Republic. In their empirical study conducted through interviews with companies, auditors and other professionals in terms of the relationship between financial statements and taxation in order to apply IFRS, the attitude of state authorities were not favorable, close link between accounting and taxation offering footprint. In opposition, the companies have demonstrated a favorable attitude, the implementation of IFRS in the relationship between financial statements and taxation, concluding that this is one of the key solutions of tax and financial accounting disconnection.

Krzywda and Schroeder (2007) identified the causes of quantitative (for 2001 and 2003) and qualitative (for 2004) differences of financial statements between IFRS and Polish Accounting Regulations (PAR) for Listed Entities on the Warsaw Stock Exchange (WSA). The study concludes that taxation is one of the causes for differences between the two regulations (PAR and IFRS).

Jaruga et al. (2007) analyzed the impact of IAS/IFRS on PAR for Listed Entities on the WSA. In the implementation process of IAS/IFRS for Listed Entities, the authors found the areas where significant changes have occurred, in these changes taxation having an important role.

\section{Review of Romanian literature}

Romanian authors conducted also taxation research in accounting; their research method was primarily analytical, the focus being both local and international. Ciumag, for example, (Ciumag, 2004) performed a comparative analysis of the accounting and tax rules in Romania. The author emphasizes that there are divergences between them, besides the many common elements manifested. To identify these differences, analysis of how the principles of accounting are influenced by tax considerations may be significant.

Berinde and Răchişan (2005) consider the state as the most important user, especially in case of SMEs, for this reason accounting must be influenced by taxation. This particular aspect was largely debated in the Romanian academic and professional forums/conferences, in the literature and also in course books (Matiş, 2005; Matiş and Pop, 2007). For example, Berinde (2004) analyzed the introduction of the concept of deferred (income) tax in the Romanian legislation as the early effort towards the separation of accounting from taxation.

Petre and Lazăr (2006) argue that the regulation of accounting is not connected to taxation. In practice the entities might use fiscal instead of accounting rules, but this pertains to practice and not regulation, "there is no subordination of accounting to taxation and accounting rules are not harmonized with fiscal rules." (Petre and Lazăr 2006: 6) They consider that "such opinion that accounting serves fiscal interests represents at least not knowing the current Romanian reality" (Petre and Lazăr 2006: 6).

In Romania, as in other European countries (France, Germany, etc.) accounting is obviously influenced by taxation (Paliu-Popa and Ecobici, 2007) if we take into account the fact that the norms specific to fiscal law and to accounting law are drawn up by the same organic structure, which is the Ministry of Public Finance that imposes regulations and procedures.

Berinde (2006) considers that in Romania there is the possibility of gradually opening the way toward an efficient accounting system, in which the accounting and taxation operate independently of each other. A disconnection between accounting and taxation should be associated 
with a reduced rate of taxation. The consequence is reducing country risk and thus a favorable country report for Romania.

Hence financial accounting and taxation accounting are not the same (Cotleț and Megan, 2007). In theory they have different objectives, are subject to different rules and serve different purposes. Financial accounting involves the preparation of information for the purpose of private decision-makers while the taxation accounting's main purpose is to raise revenue for the public authority (state), being an excellent instrument of government economic and social policy.

In studying the accounting-taxation systems' relation, $\square$ teț (2008) affirms that it is difficult to establish a priority relation, both are conditioning each other. On the one side, the accounting offers the subject for taxation system in the phase of determination the fiscal duties and, on the other side the taxation system influences the accounting by specific regulations.

According to Bunget and Dumitrescu (2008) the relationship between accounting and taxation still represents a field of convergence and divergence, of tolerance and intolerance. Therefore, the Romanian accountant is in permanent pursuit of quality accounting information and its impact on taxation.

Neamţiu (2008) takes a more international approach, focusing on the differences between Anglo-Saxon accounting system and the continental European system. The Anglo-Saxon accounting system is less fiscally polluted than the continental European system, the focus being on obtaining quality information, the basis of fiscal calculus being determined outside the accounting. The interference of taxation in accounting has a main consequence: the distortion of accounting information.

Tax accounting correlation (Lepădatu, 2008) can be outlined for the first time in the next period through settlement. For this point of view it is known that for accounting exists and it is functional an international settlement background. IASs represent professional obligatory standards and general applicable in all countries which have adopted it. In exchange, taxation remains in the national space even in the conditions of global and regional processes.

\section{Current Regulation of Accounting and Taxation in Romania}

King et al. (2001) and Ionaşcu et al. (2007) provide a very good synthesis of accounting standard setting in Romania, up the date of paper publishing. Here we analize the current situation of both accounting and taxation regulation.

Currently in Romania accounting (financial reporting) and taxation is separately regulated, but the standard setter for both is the very same authority of the state, i.e. the Ministry of Public Finance.

Accounting in Romania is regulated by the Order of the Ministry of Public Finance (OMPF) 1752/2005, which approves accounting regulations consistent with EU Directives. This act replaces OMPF 94/2001, which approved the accounting regulations in accordance with International Accounting Standards (IAS) and applicable for public entities.

The World Bank (2008) identified the key differences between IAS/IFRS and Romanian Accounting Standards (RAS). In terms of deferred taxes relating to all temporary differences needs to be recognized (IAS 12), The RAS (OMPF 1752/2005) no requirement to recognize deferred tax. A deferred tax liability may be recognized though a provision posted under "provisions" on the face of the balance sheet.

In terms of taxation, the act that regulates individual and corporate taxpayers' obligations towards the state budget, is represented by Law 571/2003 regarding the Fiscal Code and in terms of income tax, it is covered by Title II of the Law above mentioned. This title establishes the taxpayers who owe income tax, tax rate, and the way of establishment of taxable profit (incomes not taxable, not deductible expenses, and reserves that are deductible in calculating taxable profit). Under section 38 of the rules for the application of the Fiscal Code "Deferred tax expenses, recorded by the taxpayer, are not deductible". 
The use of deferred income tax has been abolished since 2006, as Romanian legislation returned to the $4^{\text {th }}$ EU Directive. Therefore the application of IAS 12 Income taxes by Romanian companies is forbidden in their individual reports, but is allowed for listed entities in their consolidated financial statements.

\section{Model development}

As discussed in the previous section, most of the literature is theoretical, descriptive and/or analytical. Tax empirical research in accounting (both in Europe and elsewhere) is rather scanty, existing literature focusing on the income elements affected by fiscal rules on both normative (de jure) and practical (de facto) level, i.e. negative and positive temporary or permanent differences. These methods are useful and interesting, since they compare the accounting and fiscal treatment of transactions affecting income elements, some of them between countries (Gallego, 2004; Ebenhartinger, 1999; Lamb et al.,1998; Blake et al., 1993). However, these studies cannot capture the overall fiscal influence over accounting, which could be an important factor in understanding the degree to which accounting data is biased for fiscal purposes, often referred in the literature as dependence or connection between accounting and taxation.

Previous literature (Ebenhartinger, 1999; Gallego, 2004) and also accounting regulations consider accounting income as a proxy for accounting effects and taxable income (income tax basis) as the most appropriate proxy for fiscal effects. Gallego (2004, p.797) considers, that "the calculation of two different figures following different methodologies gives rise to the existence of important differences between both types of income". In such a case accounting is considered being disconnected from taxation.

The computation of accounting income or profit before tax (PBT) is based, however, not only on legal requirements, but it contains also managerial discretion, referred as "professional judgment" by IASB, such as (Fekete, 2008):

- Measurement decisions (accounting estimates): depreciation and amortization (useful life, residual value, depreciation method), impairment (recoverable amount, fair value less costs to sell, value in use, net realizable value), provisions, fair value estimates, level of significance

- Recognition decisions: assets vs. expenses, revaluations

- Timing decisions: recognition of revenues/expenses and gains/losses

- Disclosure decisions - these have no effect on the computation of PBT.

Such opportunistic behavior occur to meet shareholder demands (expected earnings) both as accounting profit and fiscal (income tax) optimization. Therefore, accounting income (PBT) is not an appropriate measure for accounting numbers, since it might already contain fiscal influence, for example, in Romania many companies use the useful life and depreciation methods accepted by the tax authority instead of best estimates; provisions are recognized depending on their tax deductibility and not their financial usefulness; revaluation of tangibles are carried out to minimize local tax on property and not to reflect their fair value.

For these reasons we went backward on the earnings computation line, as shown in Fig. no. 1, and finally we chose Sales as the best indicator of accounting effect as explained below:

- EBIT (Earnings before interest and taxes) and operating profit (profit from operations) are both affected by depreciation and amortization choices, as well as inventory valuation and product costing choices;

- EBITDA (Earnings before interest, taxes, depreciation and amortization) is affected by inventory valuation and product costing choices;

- Sales is least affected by tax rules; it is still influenced by accounting choices. 


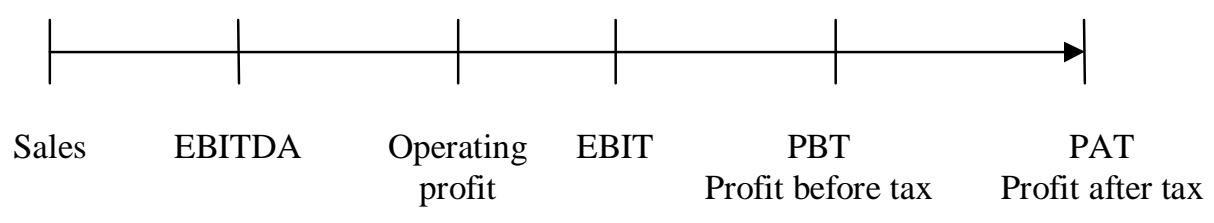

Fig. no. 1 - Earnings computation line

We capture taxation effects in terms of taxable income. Since in Romania there is only one income tax coefficient (since 2005 it is uniformly $16 \%$ for all legal entities), we can substitute this amount with the value of income tax. Income tax, however, could not been observed (as described in data management section), therefore we computed this value as PBT less PAT.

Consequently, the model proposed for measuring the fiscal influence over accounting is:

$$
\text { Sales }=\mathrm{f}(\text { PBT }- \text { PAT })
$$

Unfortunately this model does not control for timing of recognition issues, which could be taken in consideration, for example, by computing average values for a certain observation period (instead of having only one value of a financial year). Since this method requires considerable data, we chose to compute marginal values, i.e. marginal sales, marginal taxes.

Accordingly, the model changes to a dynamic form:

$$
\triangle \text { Sales }=\mathrm{f}[\triangle(P B T-P A T)]
$$

This model, however, is strongly affected by scale effect. Jones (1991) introduces a control for size effect deflating all variables by total asset value at the beginning of the year. Finally, the proposed econometric model is:

$$
\begin{aligned}
& \frac{\Delta \text { Sales }_{t, j}}{A_{t-1, j}}=\alpha_{0}+\alpha_{1} \frac{\Delta \operatorname{Tax}_{t, j}}{A_{t-1, j}}+\varepsilon \\
& \Delta \text { Sales }_{t, j}=\text { Sales }_{t, j}-\text { Sales }_{t-1, j} \\
& \Delta \text { Tax }_{t, j}=\left(P B T_{t, j}-P A T_{t, j}\right)-\left(P B T_{t-1, j}-P A T_{t-1, j}\right)
\end{aligned}
$$

where:

Sales $_{t, j}$ - Sales for financial year $t$ and firm $j$;

$P B T_{t, j} \quad$ - Profit before tax for financial year $t$ and firm $j$;

$P A T_{t, j} \quad$ - Profit after tax for financial year $t$ and firm $j$.

The period under observation, sample of firms and data collection are explained in the next section.

\section{Data Management}

As suggested in the title, our study is performed on Romanian data, albeit, there is no restriction in its use on a specific country.

The period we initially intended to observe was 2006-2008, since in this period there were no significant changes in accounting or fiscal regulations in Romania. But, due to data collection problems, we restricted our observation period to year 2008, these data being the most recent available financial data.

As explained earlier, the fiscal influence over accounting numbers seems to vary by firm size: while big entities clearly separate their accounting and tax records, SMEs have mixed records, then the micro entities have (almost exclusively) tax records in their accounting system.

Defining a representative sample and collecting data on all the three levels would much exceed our possibilities; therefore a compromise solution had to be accepted. We restricted our sample on listed companies, considering that if we can detect fiscal influence over accounting on this level, the expected influence on lower levels would be even higher.

Sample definition is explained in Table no. 1 below. 
Table no. 1

Sample description

\begin{tabular}{|c|c|}
\hline \begin{tabular}{|l} 
Explanations \\
\end{tabular} & No. of entities \\
\hline Romanian listed companies at the end of 2008 , of which & 1.688 \\
\hline on BSE, of which & 101 \\
\hline Tier I & 21 \\
\hline Tier II & 47 \\
\hline Tier III & 1 \\
\hline International & 1 \\
\hline suspended & 31 \\
\hline on RASDAQ, of which & 1.587 \\
\hline Tier I-R & 6 \\
\hline Tier II-R & 9 \\
\hline Tier III-R & 1.572 \\
\hline \multicolumn{2}{|l|}{$\begin{array}{ll}\text { Less: } \\
\end{array}$} \\
\hline - financial entities (banks, mutual funds, insurance), of w. & 13 \\
\hline BSE & 10 \\
\hline RASDAQ & 3 \\
\hline - companies with negative results in any of 2005-2008 & 562 \\
\hline BSE & 24 \\
\hline RASDAQ & 538 \\
\hline - companies excluded for data management reasons & 680 \\
\hline BSE & 31 \\
\hline RASDAQ & 649 \\
\hline Companies included in the range, of which & 433 \\
\hline BSE & 36 \\
\hline RASDAQ & 397 \\
\hline Companies selected in the sample, of which & 210 \\
\hline BSE & 36 \\
\hline Tier I & 8 \\
\hline Tier II & 28 \\
\hline Tier III & 0 \\
\hline International & 0 \\
\hline RASDAQ & 174 \\
\hline Tier I-R & 1 \\
\hline Tier II-R & 5 \\
\hline Tier III-R & 168 \\
\hline
\end{tabular}

$B S E=$ Bucharest Stock Exchange, $R A S D A Q=$ Romanian Association of Securities Dealers Automated Quotation (system)

Source: designed by the authors

We included in the sample both BSE and RASDAQ listed companies, since both categories are publicly traded "big" entities and publish their financial data. Some companies however have been excluded, such as:

- suspended companies at the end of year 2008;

- financial institutions, because of the nature of their activity, they being regulated also by the National Bank of Romania;

- companies with negative results in any of the years 2005-2008; these entities were excluded because income taxation is defined only in the positive range (there is no tax 
refund in case of accounting loss that would lead to negative taxation income and negative income tax);

- Some companies were excluded for data management reasons because we could not find all the financial data for the observed company.

Out of the 433 companies considered eligible for participating in the sample definition, we selected about half (210) of the companies as follows: all the eligible (36) companies from BSE have been considered, the rest of 174 entities have been selected randomly.

Data for all the variables described in the previous section (Sales, PBT, PAT, Total assets) have been collected from individual financial statements for financial year 2008 of entities from the following sources:

- Our primary source was www.bvb.ro, where we consulted each company's key financials;

- We completed this database with missing data from www.mfinante.ro;

- Sometimes we consulted the individual webpage of a company if confirmation of data was necessary.

Since we use individual financial statements, all accounting data is computed based on Romanian accounting standards in force.

In Table no. 2 panel A below we present some basic descriptive information of our database; panel B emphasizes change in variability of some variables due to deflation by total assets. We can observe a drop in the coefficients of variation (standard deviation divided by mean).

Nevertheless, our dynamic variables $\left(\Delta \mathrm{Sales}_{2008} / \mathrm{A}_{2007} ; \Delta \mathrm{Tax}_{2008} / \mathrm{A}_{2007}\right)$ are much more dispersed than their static equivalent; we believe these variables reflect the best the "true" variations of accounting and tax numbers.

Table no. 2

Descriptive statistics

\begin{tabular}{|c|c|c|c|c|c|}
\hline \multicolumn{6}{|c|}{ PANEL A. DESCRIPTIVE CHARACTERISTICS OF VARIABLES EMPLOYED } \\
\hline $\begin{array}{c}\text { Variable } \\
\text { name }\end{array}$ & Range & $\begin{array}{l}\text { Minimum } \\
\text { value }\end{array}$ & $\begin{array}{l}\text { Maximum } \\
\text { value }\end{array}$ & Mean & $\begin{array}{l}\text { Standard } \\
\text { deviation }\end{array}$ \\
\hline Sales $_{2008}$ & 16.750 .654 .723 & 71.734 & 16.750 .726 .457 & $157.499 .925,67$ & $1.179 .571 .785,26$ \\
\hline $\mathrm{PBT}_{2008}$ & 1.605 .562 .408 & 932 & 1.605 .563 .340 & $14.504 .122,15$ & $114.344 .297,15$ \\
\hline $\mathrm{PAT}_{2008}$ & 1.022 .387 .399 & 64 & 1.022 .387 .463 & $10.503 .432,65$ & $74.312 .588,55$ \\
\hline $\mathrm{A}_{2007}$ & 21.160 .195 .916 & 837.643 & 21.161 .033 .559 & $203.132 .238,39$ & $1.500 .739 .832,31$ \\
\hline $\begin{array}{l}\text { Sales }_{2008} \\
\mathrm{~A}_{2007}\end{array}$ & 4,5140 & 0,0216 & 4,5356 & 1,0585 & 0,7281 \\
\hline $\begin{array}{l}\mathrm{PBT}_{2008} \\
\mathrm{~A}_{2007}\end{array}$ & 3,2012 & 0,0003 & 3,2015 & 0,0921 & 0,2409 \\
\hline $\begin{array}{l}\mathrm{PAT}_{2008} \\
\mathrm{~A}_{2007}\end{array}$ & 2,6571 & 0,0000 & 2,6571 & 0,0771 & 0,2011 \\
\hline $\mathrm{Tax}_{2008} / \mathrm{A}_{2007}$ & 0,5443 & 0,0000 & 0,5443 & 0,0151 & 0,0406 \\
\hline $\begin{array}{l}\Delta \text { Sales }_{2008} \\
\mathrm{~A}_{2007}\end{array}$ & 3,1595 & $-1,0857$ & 2,0738 & 0,0989 & 0,3209 \\
\hline $\begin{array}{ll}\Delta \operatorname{Tax}_{2008} & / \\
\mathrm{A}_{2007} & \\
\end{array}$ & 0,5040 & $-0,0821$ & 0,4220 & 0,0022 & 0,0329 \\
\hline \multicolumn{6}{|c|}{ PANEL B. CHANGES IN CHARACTERISTICS DUE TO TRANSORMATIONS } \\
\hline $\begin{array}{c}\text { Variable } \\
\text { name }\end{array}$ & $\begin{array}{c}\text { Coefficient of } \\
\text { variation }\end{array}$ & & Variable name & $\begin{array}{c}\text { Coefficient of } \\
\text { variation }\end{array}$ & \\
\hline Sales $_{2008}$ & 7,4893 & & $\mathrm{Sales}_{2008} / \mathrm{A}_{2007}$ & 0,6879 & \\
\hline $\mathrm{PBT}_{2008}$ & 7,8836 & & $\mathrm{PBT}_{2008} / \mathrm{A}_{2007}$ & 2,6156 & \\
\hline
\end{tabular}




\begin{tabular}{|l|r|l|l|r|r|}
\hline $\mathrm{PAT}_{2008}$ & 7,0751 & & $\mathrm{PAT}_{2008} / \mathrm{A}_{2007}$ & 2,6083 & \\
\hline $\mathrm{A}_{2007}$ & 7,3879 & & $\mathrm{Tax}_{2008} / \mathrm{A}_{2007}$ & 2,6887 & \\
\hline & & & & & \\
\hline$\Delta$ Sales $_{2008} /$ & 3,2447 & & & & \\
$\mathrm{~A}_{2007} \quad /$ & 14,9545 & & & & \\
\hline$\Delta \operatorname{Tax}_{2008}$ & & & & \\
$\mathrm{~A}_{2007}$ & & & & & \\
\hline
\end{tabular}

Number of observations (firms): $N=210$

Non-deflated variables are expressed in RON, deflated variables are expressed as coefficients. Source: calculation of authors

\section{Interpretation and Discussion of Results}

As we discussed in the model development section, we employ model (3) in the empirical analysis because this model version is best specified and provides the best proxy for the level of accounting-taxation cohabitation. Our findings are summarized in Table no. 3.

Table No. 3

OLS regression model

\begin{tabular}{|c|c|c|c|c|c|}
\hline \multicolumn{6}{|c|}{ MODEL: $\frac{\Delta \text { Sales }_{t, j}}{A_{t-1, j}}=0,094+2,034 \cdot \frac{\Delta \text { Tax }_{t, j}}{A_{t-1, j}}+\varepsilon$} \\
\hline Variables & Alfa & $\mathrm{t}$ & Signif. & $\begin{array}{c}\mathrm{F} \\
\text { (Signif.) }\end{array}$ & Adj. $R^{2}$ \\
\hline Constant & 0,094 & 4,336 & 0,000 & $\begin{array}{c}9,457 \\
(0,002)\end{array}$ & 0,039 \\
\hline$\Delta \operatorname{Tax} / \mathrm{A}$ & 2,034 & 3,075 & 0,002 & & \\
\hline
\end{tabular}

As our statistical analysis confirms there is indeed a fiscal influence on accounting numbers provided by Romanian listed companies, the level of this influence being according to our measurement about 4\% (Adj. $\mathrm{R}^{2}=0,039$ ). The validity of the relationship is confirmed by significance levels, since both the tax variable and model are significant, we can state that this influence is indeed statistically significant (Signif. $<0,002$ ).

In the Romanian literature is suggested that accounting is (still) considerably influenced by taxation. The question is therefore can we interpret this $4 \%$ level as an evidence for "strong influence"?

If one considers that there are many factors, such as economic, social, political, financial (including fiscal) manifesting on both macro- and microeconomic level that accounting integrates in producing its numbers, we can conjecture this influence is rather high. On the other hand, based on a statistical approach, $4 \%$ influence is rather low (the independent variable explains about $4 \%$ of the variance of the dependent, as displayed on Figure no. 2). As a result, in our case we consider, that the level of influence cannot be interpreted as "high" or "low", since we have no benchmark value.

Therefore, our results confirm the existence of fiscal influence over accounting in case of Romanian listed companies, but it does not support the overwhelming opinion in the Romanian literature, that the taxation has a considerable influence on accounting. 


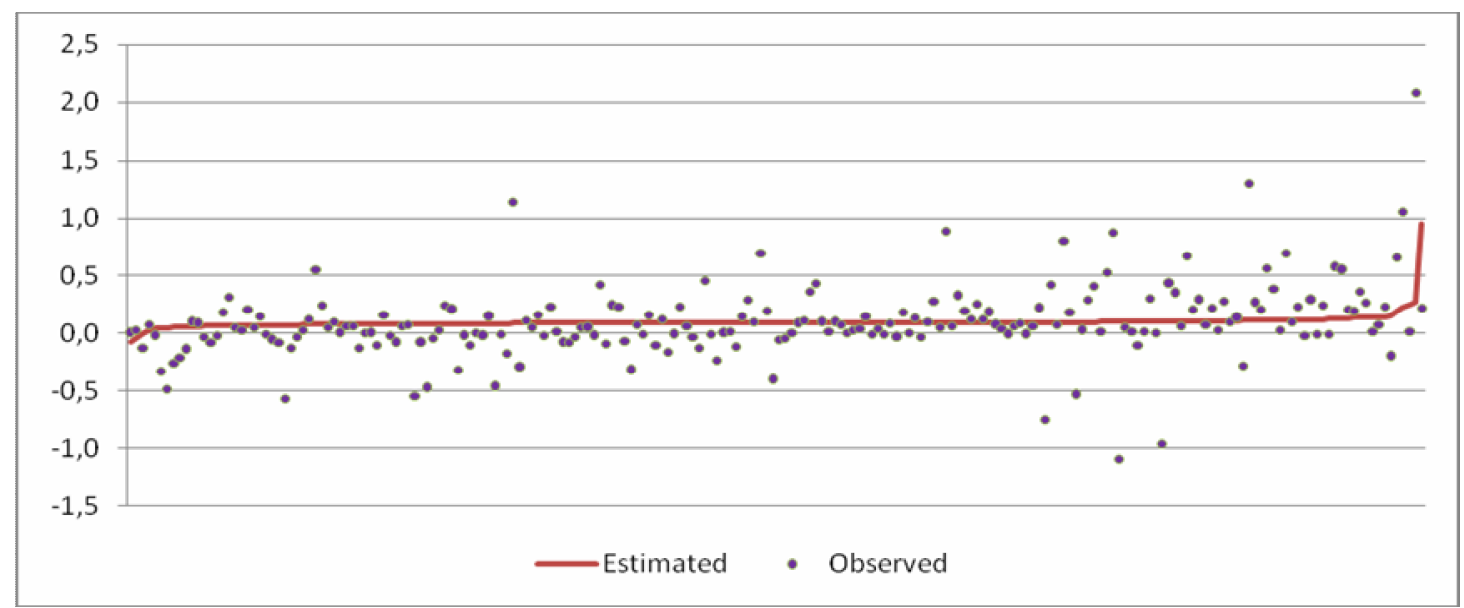

Fig. no. 2 - Estimated vs. observed change in deflated sales

Analyzing the histogram of the residual component (Fig. no. 3) we can observe the conspicuous frequency of small negative errors (we have about 90 observations here, which is almost half of the cases in the sample). Additionally, there are some extreme outlier companies that have very high positive residual. We believe this might be an indicator that our sample is not homogeneous; and indeed we chose companies from both BSE and RASDAQ with very diffuse observations for all the variables as presented in Table no. 2.

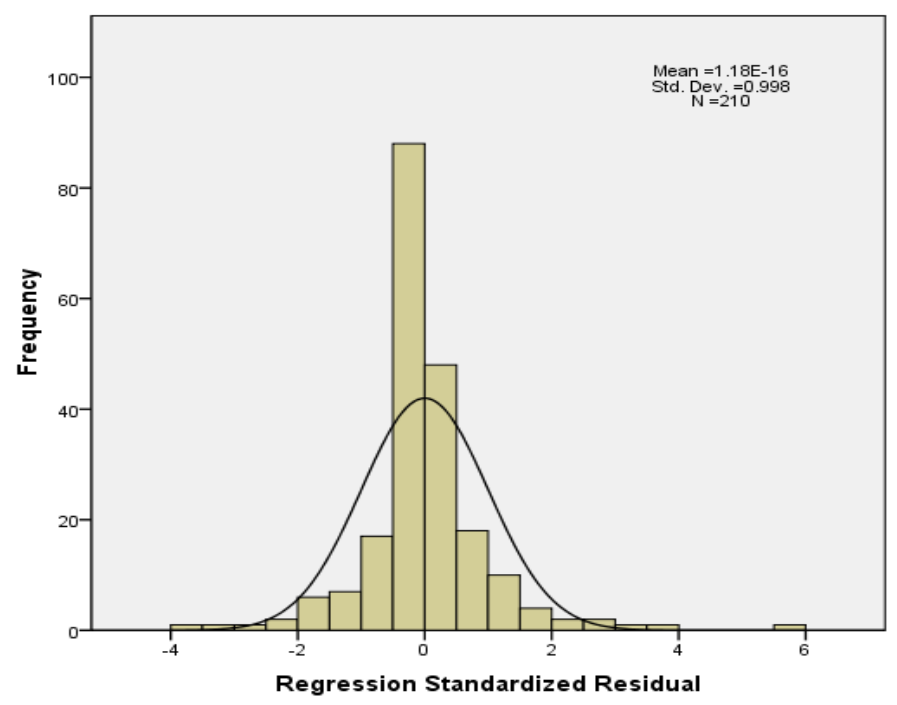

Fig. no. 3 - Histogram of residual component ( $(\varepsilon)$

One possible solution to eliminate heterogeneity and also to check the robustness of the results (and the model) is redefining the sample. Following this logic we split the original sample into two sub-samples: companies from BSE (36 entities) and separately, companies from RASDAQ (174 entities). The results obtained are presented in Table no. 4 below. 
OLS regression models for sub-samples

\begin{tabular}{|c|c|c|c|c|c|c|c|c|c|}
\hline \multicolumn{5}{|c|}{ BSE sub-sample $(n=36)$} & \multicolumn{5}{|c|}{ RASDAQ sub-sample $(n=174)$} \\
\hline \multicolumn{2}{|c|}{$\frac{\Delta \text { Sales }_{t, j}}{A_{t-1, j}}$} & \multicolumn{3}{|c|}{$\frac{\Delta \operatorname{Tax}_{t, j}}{A_{t-1, j}}$} & \multicolumn{5}{|c|}{$\frac{\Delta \text { Sales }_{t, j}}{A_{t-1, j}}=0,104+1,954 \cdot \frac{\Delta \operatorname{Tax}_{t, j}}{A_{t-1, j}}+\varepsilon$} \\
\hline Variables & Alfa & $\begin{array}{c}\mathrm{t} \\
\text { (Signif.) }\end{array}$ & $\begin{array}{c}\mathrm{F} \\
\text { (Signif.) }\end{array}$ & $\begin{array}{l}\text { Adj. } \\
\mathrm{R}^{2}\end{array}$ & Variables & Alfa & $\begin{array}{c}\mathrm{t} \\
\text { (Signif.) }\end{array}$ & $\begin{array}{c}\mathrm{F} \\
\text { (Signif.) }\end{array}$ & $\begin{array}{l}\text { Adj. } \\
\mathrm{R}^{2}\end{array}$ \\
\hline Constant & 0,047 & $\begin{array}{c}1,824 \\
(0,077) \\
\end{array}$ & \multirow{2}{*}{$\begin{array}{c}7,075 \\
(0,012)\end{array}$} & \multirow{2}{*}{0,148} & Constant & 0,104 & $\begin{array}{c}4,046 \\
(0,000) \\
\end{array}$ & \multirow{2}{*}{$\begin{array}{c}7,512 \\
(0,007)\end{array}$} & \multirow{2}{*}{0,036} \\
\hline$\Delta \operatorname{Tax} / \mathrm{A}$ & 9,165 & $\begin{array}{c}2,660 \\
(0,012)\end{array}$ & & & $\Delta \operatorname{Tax} / \mathrm{A}$ & 1,954 & $\begin{array}{c}2,741 \\
(0,007)\end{array}$ & & \\
\hline
\end{tabular}

Source: calculation of authors

As we can see, both models and the tax variable within both are significant, which further confirms that there is fiscal influence over accounting in both sub-samples (RASDAQ and BSE companies). The finding concerning the level of this influence, however, is more than interesting: in RASDAQ sample we found a 3,6\% influence, which seems to be in line with our previous results. But, in the BSE sample the level of influence has an unexpected value of almost $15 \%$.

This is in contradiction to our expectation: we presumed that big sized entities' accounting data are less influenced by taxation that smaller ones. At this level of our research we cannot provide any explanation to this inconsistency.

\section{Conclusions and future research}

In this paper we attempted to measure the influence of taxation over accounting. The model we proposed seems to capture this influence and permits also statistical testing. Our results suggest that taxation explains about $4 \%$ of accounting information, which we interpret as the level of fiscal influence over accounting. As previously discussed, this cannot be considered "high" or "low", since we have no basis for comparison.

We are aware of the limitations of this study also. As presented in the section of the literature it is established that not only taxation affects accounting, but accounting also influences taxation (Lamb et al., 1998). The model proposed by us cannot capture this reverse relationship, since we hypothesized the relationship being uni-directional: taxation influences accounting.

Model specification might be problematic also; we argued and explained in detail the choice in proxy variables (Model development). One of our dilemmas is whether we should take in consideration accruals or not in such a model.

Another limitation is related to our results: it is puzzling that the R-square for BSE companies is about $15 \%$, which is almost 4 times higher than the R-square on the original sample. There are plenty of opportunities for future research. On this level of comprehension the following questions should be further analyzed: (1) robustness check of the model on panel data; (2) robustness check of the model on SMEs and possibly on micro entities; (3) further testing by using data from other countries; (4) extend the model on cross-country level.

\section{References}

1. Aisbitt, S., 2002. Tax and accounting rules: some recent developments. European Business Review, pp. 92-97.

2. Berinde, S., Răchişan, R., 2005. Taxes impact on accounting. Paper published in the volume of Accounting Section of the International Conference „The Impact of European Integration on the National Economy", Babeş-Bolyai University of Cluj-Napoca, Faculty of Economics and Business Administration, October, pp. 201-208. 
3. Berinde, S., 2004. Normalizarea, armonizarea şi perspective deconectării contabilităţii de fiscalitate. Paper published in the volume of international conference „Audit and Accounting Convergence", Babeş-Bolyai University of Cluj-Napoca, Faculty of Economics and Business Administration, pp. 523-533.

4. Berinde, S., 2006. Contabilitatea şi Fiscalitatea veniturilor si rezultatelor entităţilor economice. Doctoral Thesis, Babes-Bolyai University, Cluj-Napoca, Romania.

5. Blake, J., Akerfeldt, K., Fortes, H., Gowthorpe, C., 1997. The relationship between tax and accounting rules - the Swedish case. European Business Review 97 (2), pp. 85-91.

6. Blake, J., Amat, O., Fortes, H., 1993 „The Relationship between tax regulations and Financial Accounting: a comparison of Germany, Spain and the United Kingdom”. Working paper available on-line at http://www.econ.upf.edu/docs/papers/downloads/46.pdf

7. Blake, J., Amat, O., Growthorpe, C., Pilkington, C., 1998. International accounting harmonization - a comparison of Spain, Sweden and Austria. European Business Review 98 (3), pp. 144-150.

8. Bosnyák, J., 2003. Számviteli értékelési eljárások hatása a vállalkozások vagyoni, jövedelmi és pénzügyi helyzetére [The effect of evaluation methods on the financial position, performance and cash flows of entites]. Doctoral thesis, Corvinus University, Budapest, Hungary.

9. BSE Bucharest Stock Exchange http://www.bvb.ro/Companies/ListedCompanies.aspx

10. Bunget, O.C., Dumitrescu, A.C., 2008. Accounting treatment of deferred income taxes according to the requirements of the Romanian accounting regulations. Article published in The Annals of University of Oradea - Economic Science, Tom XVII, vol.3, section Finances, Banks and Accounting, pp. 1039-1043, available on-line at http://steconomice.uoradea.ro/ anale/en volum-2008-finance-bank-accountancy.html

11. Chauveau, B., 1995. The Spanish Plan General de Contabilidad - Agent of development and innovation? European Accounting Review, pp. 125-138.

12. Ciumag, M., 2004 „Accounting principles and Fiscal Rules”, available on-line at http://mpra.ub.uni-muenchen.de/14963

13. Cotlet, D., Megan, O. 2007. The Romanian accounting information under the pressure of providers and users. Article published in Annals of the University of Petroşani, Economics, no.7, pp. 83-92, available on-line at http://www.britanica.com/bps/additional content $/ 18 / 31705556$

14. Desai, M., 2005. The degradation of corporation profits. Journal of Economic Perspectives 19 (Fall), pp. 171-192.

15. Eberhartinger, E., Klostermann, M., 2007. What If IFRS were a tax base? New empirical evidence from an Austrian perspective. Accounting in Europe 4 (2), pp. 141-168.

16. Eberhartinger, E., 1999. The impact of tax rules on financial reporting in Germany, France and the UK. The International Journal of Accounting 34 (1), pp. 93-119.

17. Fekete, Sz., 2008. Cercetare conceptuală şi empirică privind raportările financiare. Cazul sistemului contabil românesc şi maghiar (Conceptual and empirical research in financial reporting. The case of the Romanian and Hungarian accounting systems). Doctoral Thesis, Babes-Bolyai University, Cluj-Napoca, Romania.

18. Fekete, Sz., Damagum, Y.M., Mustață, R., Matiş, D., Popa, I., 2008. Explaining accounting policy choices of SMEs. Empirical research on the evaluation methods. Working paper presented in the conference ,3rd Audit and Accounting Convergence 2008 Annual Conference", Babeş-Bolyai University, Cluj-Napoca, Romania.

19. Feleagă, N., 1999. Sisteme contabile comparate, Vol. I, ediția a-II-a. Editura Economică, Bucureşti, pp. 21.

20. Gallego, I., 2004. The Accounting and taxation relationship in Spanish listed firms. Managerial Auditing Journal 6, pp. 796-819 
21. Gallego, I., Garcia, I.M., 1999. Aspectos contables y fiscales de las Uniones Temporales de Empresas: un estudio empirico. Paper presented at the I Jornadas de Contabilidad Financiera, Madrid, Spain.

22. Guenther, D., Maydew, E., Nutter, S., 1997. Financial Reporting, tax costs, and book-tax conformity. Journal of Accounting and Economics (November), pp. 225-248.

23. Haller, A., 1992. The relationship of financial and tax accounting in Germany: a major reason for accounting disharmony in Europe. International Journal of Accounting, pp. 310323.

24. Hanlon M., Maydew E., Shevlin T., 2008. An Unintended consequence of book-tax conformity: a loss of earnings informativeness. Journal of Accounting and Economics, pp. 294-311.

25. Hoogendoorn, M., 1996. Accounting and taxation in Europe - a comparative overview. The European Accounting Review 5 (Supplement), pp. 783-794.

26. IASB, 2007. Standarde internaționale de raportare financiară (IFRSs): incluzând Standardele internaționale de contabilitate (IASs) si Interpretările lor la 1 ianuarie 2007. CECCAR, Bucuresti.

27. IASB, 2008. Electronic International Financial Reporting Standards (eIFRSs). Accessed through IAAER http://www.iaaer.org/ on 20.09.2009.

28. Ionaşcu, I., Ionaşcu, M., Olimid, L., Calu, D.A., 2007. An Empirical Evaluation of the Costs of Harmonizing Romanian Accounting with International Regulations (EU Directives and IAS/IFRS). Accounting in Europe 4 (2), pp. 169-206.

29. Istrate, C. 1999. Fiscalitate $\square$ i contabilitate în cadrul firmei. Editura Polirom, Ia $\square$ i, pp. 2226.

30. Jaruga, A., Fijalkovska, J., Jaruga-Baranowska, M., Frendzel, M., 2007. The impact of IAS/IFRS on Polish Accounting Regulations and their practical implementation in Poland, Accounting in Europe 4 (1), pp. 67-78.

31. Jones, J., 1991. Earnings management during import relief investigations. Journal of Accounting Research 29 (2), pp. 193-228.

32. King, N., Beattie, A., Cristescu A.M., 2001. Developing accounting and audit in a transition economy: the Romanian experience. The European Accounting Review 10 (1), pp. 149-171.

33. Krzywda, D., Schroeder, M., 2007. An Analysis of the differences between IFRS and Polish Accounting Regulations: evidence from the financial statements of listed entities on the Warsaw Stock Exchange for the calendar years ending 2001, 2003 and 2004. Accounting in Europe 4 (1), pp. 79-107.

34. Lamb, M., Nobes, C., Roberts, A., 1998. International variations in the connections between tax and financial reporting. Accounting and Business Research 3, pp.173-188.

35. Lepădatu, V.G., 2008. „Fiscal-accounting correlation in the global era”. Article published in Metalurgia Review, număr special 1, available on-line at www.metalurgia.ro

36. Manzon, G., Plesko, G., 2002. The Relation between financial and tax reporting measures of income. Tax Law Review 55 (2), pp. 175-214.

37. Martinez, J., Labatut, G., 1997. La contabilización del impuesto sobre sociedades. Un estudio empirico de su aplicación en la empresa Valenciana. Actualidad Financiera.

38. Matiş, D., Pop, A., (Eds.) 2007. Contabilitate financiară [Fiancial accounting]. Alma Mater Press, Cluj-Napoca, Romania.

39. Matiş, D., (Ed.) 2005. Bazele contabilităţii. Aspecte teoretice şi practice [Basic Accounting. A theoretical and practical approach], Alma Mater Press, Cluj-Napoca, Romania.

40. MPF Ministry of Public Finance http://www.mfinante.ro/contribuabili/ link.jsp?body=/contribuabili/ agenti cod.jsp

41. Neamţiu, G., 2008. Accounting information and fiscal pollution. Article supported at International Conference „Theoretical Developments in Contemporary Economics” in 
University Aurel Vlaicu Arad, Faculty of Economic Sciences, pp. 442-445, available on-line at www.conferinta.uav.ro/php/part2.php

42. Nobes, C., Oliveras, E., Puig, X., 2004 ,The changing relationship between tax and financial reporting in Spain", working paper available on-line at http://papers.ssrn.com/sol3/ papers.cfm? abstract_id=848667\#208417

43. Paliu-Popa, L., Ecobici, N., 2007 „Accounting Implications of Taxation”, available on-line at: http://mpra.ub.uni-muenchen.de/12186

44. Pavlik, L., 2001. A halasztott adók hatásáról: A halasztott adók potenciális nagyságának és részvényárfolyamokra gyakorolt hatásának becslése egy empírikus kutatás nyomán [Estimating the potential volume and the influence on share prices of deferred taxes based on an empirical study]. Számvitel, adó, könyvvizsgálat 43 (2), pp. 73-77.

45. Petre, G., Lazăr, A., 2006. Agenții economici au o contabilitate subordonată fiscalității? Revista Finanţe Publice şi Contabilitate 6, pp. 5-6.

46. Ristea, M., 1995. Contabilitatea societătilor comerciale, Vol. I. Editura CECCAR, Bucuresti, pp.75-80.

47. Scholes, M., Wolfson, M., Erickson, M., Maydew, E., Shevlin, T., 2005. Taxes and business strategy: a planning approach. Pearson Prentice-Hall, Upper Saddle River, NJ 07458, USA.

48. Şteț, M., 2008. The Transport service with specific characteristics - accounting and fiscal peculiarities, MTC Academic Journal 3, pp. 71-75, available on-line at www.mtc_aj.com/conf_2008/dok_259.pdf

49. Stoianoff, N.P., Kaidonis, M.A., 2005. Rehabilitation of mining sites: do taxation and accounting systems legitimise the privileged or serve the community? Critical Perspectives on Accounting, pp. 47-59.

50. Sucală, L., 2002. Contabilitate si fiscalitate. Editura Casa Cărții de Ştiință, Cluj-Napoca, Romania pp..27-35.

51. Sucher, P., Jindrichovska, I., 2004. Implementing IFRS: a case Study of the Czech Republic. Accounting in Europe 1 (1), pp. 109-141.

52. Tzovas, C., 2006. Factors influencing a firm's accounting policy decisions when tax accounting and financial accounting coincide. Managerial Auditing Journal 4, pp.372-386.

53. Walton, P., Haller, A., Raffournier, B., 2003. International Accounting. Thomson Learning, London, UK.

54. World Bank, 2008. Report on the observance of standards and codes (ROSC). Accounting and Audit, Romania. Principal author: Pascal Frèrejacque; available on-line at http://siteresources.worldbank.org/ROMANIAEXTN/Resources/Romania_Final_A\&A_RO $\underline{\text { SC.pdf }}$

55. $* * *$ Legea 571/2003 privind Codul Fiscal, Monitorul Oficial, nr. 927/22.12.2003 [Law no. 571/2003 on the Fiscal Code, Official Journal no. 927/22.12.2003].

56. *** Ordinul MFP nr. 907/2005 privind aprobarea categoriilor de persoane juridice care aplică reglementări contabile conforme cu Standardele Internaţionale de Raportare Financiară, respective reglementări contabile conforme cu directivele europene, Monitorul Oficial, nr. 597/11.07.2005 [Order of the Minister of Public Finance no. 907/2005 for the approval of the categories of legal persons applying accounting regulations conforming to International Financial Reporting Standards and accounting regulations conforming to European Directives, Official Journal, no. 579/11.07.2005].

57. $* * *$ Ordinul MFP nr. 94/2001 pentru aprobarea Reglementarilor contabile armonizate cu Directiva a IV-a a Comunităţilor Economice Europene şi cu Standardele Internaţionale de Contabilitate. Monitorul Oficial, nr. 85/20.02.2001 [Order of the Minister of Public Finance no. 94/2001 for the approval of the accounting regulations harmonized with European Directives and International Accounting Standards, Official Journal, no. 85/20.02.2001]. 
58. $* * *$ Ordinul MFP nr. 1752/2005 pentru aprobarea reglementărilor contabile conforme cu directivele europene, Monitorul Oficial, nr. 1080 bis/30.11.2005 [Order of the Minister of Public Finance no. 1752/2005 for the approval of the accounting regulations conforming to European Directives, Official Journal, no. 1080 bis/30.11.2005]. 